\title{
Study and Preservation of Wild Relatives of Cultivated Plants of the Northern Tien Shan (Within Kazakhstan)
}

\author{
Gulnara Sitpayeva \\ Institute of botany and phytointroduction, Almaty, Kazakhstan
}

Email address:

sitpaeva@mail.ru

To cite this article:

Gulnara Sitpayeva. Study and Preservation of Wild Relatives of Cultivated Plants of the Northern Tien Shan (Within Kazakhstan). American Journal of Environmental Protection. Special Issue: Applied Ecology: Problems, Innovations.Vol. 4, No. 3-1, 2015, pp. 130-135.

doi: 10.11648/j.ajep.s.2015040301.30

\begin{abstract}
Modern biodiversity declining, including wild relatives of cultivated plants (WRCP) is caused by anthropogenic pressure and represents a serious threat to the world community. Since 2013 in the Institute of Botany and Phytointroduction CS MES RK the state scientific and technical program: "Botanical variety of wild relatives of cultivated plants of Kazakhstan as a source of enrichment and preservation of the agrobiodiversity gene pool for realization of the Food programme" has been realized. In 2014 the WRCP species of the natural flora of the mountain regions of Southeast Kazakhstan were the objects of researches within 4 floristic areas - the southern hillside of the Zhungar, Ile and Kungey Alatau; Ketmen, Terskey Alatau and Shu-Ile mountains. Results of researches: the Northern Tien Shan botanical diversity was revealed; mobilization of reproductive material was made; features of species structure of WRCP were studied, their phytocenosis characteristics were obtained; resource and breeding-genetic assessment of WRCP was made; their phytopathogens were revealed; passports of species of WRCP of the studied territory were made. The ridges of the Northern Tien Shan belong to the regions possessing a rather high degree of botanical diversity and due to it, they are considered to be the important objects of WRCP' concentration in Kazakhstan. The taxonomical analysis demonstrated that WRCP of the studied regions are presented by 46 families with 148 genera including 269 series. The greatest species variety of WRCPwas presented in the following families: PoaceaeBarnhart - 66 species; RosaceaeJuss. - 38, FabaceaeLindl. - 28 species. The hierarchical order of the first three leading is Poaceae, Rosaceae, Fabaceae. In 2014 the species share of 5 families increased: Asteraceae, there were 11 representatives and it became 17, Lamiaceae (9 - 13), Alliaceae (8 - 9), Caprifoliaceae (4 - 7), Polygonaceae (5 - 12).
\end{abstract}

Keywords: Wild Relatives of Cultivated Plants, Kazakhstan

\section{Introduction}

This article presents the results of research being carried out in the framework of the scientific and technical program "The botanical diversity of wild relatives of cultivated plants of Kazakhstan as a source of enrichment and genetic conservation of agro-biodiversity for implementation of the Food Program "(2013-2015) developed and implemented by the staff of RSE "Institute of Botany and Phytointroduction" CS MES RK (as the parent organization conducting research). The concept of crop wild relatives (WRCP) is interpreted by us like a number of other authors [1] quite extensively. Under WRCP we understand the natural flora species evolutionarily genetically close to cultivated plants and, above all, the species used by humans for introduction, introduction to the culture, as well as in crosses to produce improved cultivars.
From this definition it follows that WRCP include all the most genetically similar species of the genus to which the cultivated species relate.

According to Kamelin R.V. the total number of cultivated plants is estimated at about 3,000 species of seed plants, that is about $1 \%$ of their composition in the world flora [2]. As you know, Vavilov N.I. identified 8 major centers of origin and resettlement of cultivated flora. A large part of the territory of Kazakhstan applied by him to the Central Asian Center of origin of cultivated plants. In turn Sinskaya E.N. proposedto allocate 5 major geographic regions (each with its own subdomains) of the historical development of cultural flora [3]. In her understanding Kazakhstan is situated within the Mid-South-West Asian subregion of the Old Mediterranean area (which is fully consistent with the Central Asian center of Vavilov N.I.). And according to the views of Wolfe E.V. the main part of the territory of Kazakhstan should be assigned to 
the Eastern Mediterranean subregion of the Mediterranean region [4] - one of the 16 floristic regions into which this author shared the globe.

The role of biological diversity, including WRCP in human life is difficult to overestimate. For example, in the documents of the Food and Agriculture Organization (FAO) it is said: "Among all of the Earth's riches the most important for all nations and generations are plant genetic resources" [5]. However, according to FAO experts about $75 \%$ of the global genetic diversity of agricultural crops has been lost in the course of the twentieth century. The current loss of biodiversity, including diversity of the WRCP is caused, as a rule, by human factors and represents a serious threat to the international community. [6] The strategic objectives of conservation and balanced use of biological diversity is ex situ conservation of wild relatives of cultivated plants in the regions of their origin; preservation of the gene pool of local landraces of crops; creation of the bank of germplasm of rare and endangered plant speciesю

\section{Study Area \& Methods}

This work is directed to the realization of the above mentioned objectives; the results of the implementation of this program within the Kazakh part of the Northern Tien Shan (Chu-Ili mountains, ridges: Ile and Kungey Alatau; Ketmen and Terskey Alatau and the southern slopes of Dzhungar Alatau) are presented in this manuscript.The areas studied in 2014 are extremely mountainous regions of the Northern Tien Shan. The highest species diversity of flora is concentrated in the mountains. It is due to the peculiarities of geographical location, altitude, orientation of the ridge, as well as soil and climatic conditions of mountain areas. In addition, the common history of the geological formation determines the formation of species composition and originality.

While studying the flora of the WRCP of the Northern Tien Shan the classical botanical research methods were used. The main floristic method used in the field researches was route-reconnaissance method. The cameral treatment of raw material was carried out in strict accordance with all the requirements for collection, drying, sanitary processing and storage of herbarium specimens in the Herbarium (AA). The fundamental floristic reports covering the territory of Kazakhstan were used for identification of the collected material [7-10].

Vegetation was studied using traditional methods of field geobotanical studies [11-17], including geobotanical description of the main plant communities and landscape-ecological profiling. Field studies were carried out by a combination of detailed-routing method and the method of landscape ecological profiling using topographic base, space images. At points fixed on the ground by GPS device, on special geobotanical forms the detailed description of the main geobotanical prevailing over the area and plant communities was carried out. To assess the degradation degree of vegetation the variety criteria were used [18-21].

For an inventory of commercial arrays of the WRCP, development of the recommendations on the optimal mode of laying and rational use of their resource base the traditional resource keeping techniques of [22] and geobotanical studies were used with experimental plots in the key points. All obtained data were processed statistically and summarized in inventory. By a similar scheme data on stocks of raw materials in key areas possessing commercial overgrown were also processed.

Research on the diversity of micromycetes parasitizing on the WRCP included collecting herbarium material for research, description of the symptoms of defeat, mycological study, and inventory of diseases. While the territory inspection the following damages of plants were noticed: fungal coat; pustules; spot (necrosis, ulceration); mummification and so on The identification of fungi was carried out with the help of domestic and foreign determinants [23-28].

Besides for the unification of registration methods of the results of field studies, as well as the presentation of the data in the report for all the executors of the program (employees of 5 State Botanical Gardens) general guidelines were developed. In particular, there were developed: "Description form of viewpoint and collecting material (herbarium and seeds)"; "The scheme of the geobotanical description of the community"; "The form of describing particular thickets of WRCP species" (due to the determination of the resource stocks). The reminder for collecting and primary processing of seeds and the form of the "Statement of acceptance and transfer of seed samples"

To summarize the data for each species classified as wild relatives of cultivated plants Passport of the WRCP species was developed including the following characteristics: taxonomic affiliation (family, genus, species); life form (annual, herbaceous perennial, etc.); morphology description (root, stem and so on.); terms of phenological phases (flowering and fruiting); especially environmental confinement; general distribution; distribution in Kazakhstan; the place of actual registration (co-ordinates of growing place); phytocenotic role of the species (dominant, component, etc.); fungal diseases affecting this species; seed characteristics (size, shape, and so on).

Thus, according to the described methods the novelty of the research program is a comprehensive approach to the study of the WRCP of Kazakhstan: from their detection and comprehensive (floral, phytocenotic, resource and so on.) analysis to their saving in nature, in living and herbarium collections, seed banks, as well as studying their diseases and creating the electronic information database (DB).

\section{Results \& Discussion}

So, according to N.I. Vavilov [29] the greatest of diversity of cultivars and forms of cultivated plants is concentrated in the mountainous areas. He regarded them as "natural experimental stations of new race formation" for flora and fauna, as well as for humans. The taxonomic analysis of species composition showed that the WRCP of the studied regions were represented by 46 families with 148 genera 
uniting 269 species. The species composition of the leading 10 families of the WRCP combines 207 species taxa (according to "Fig. 1").

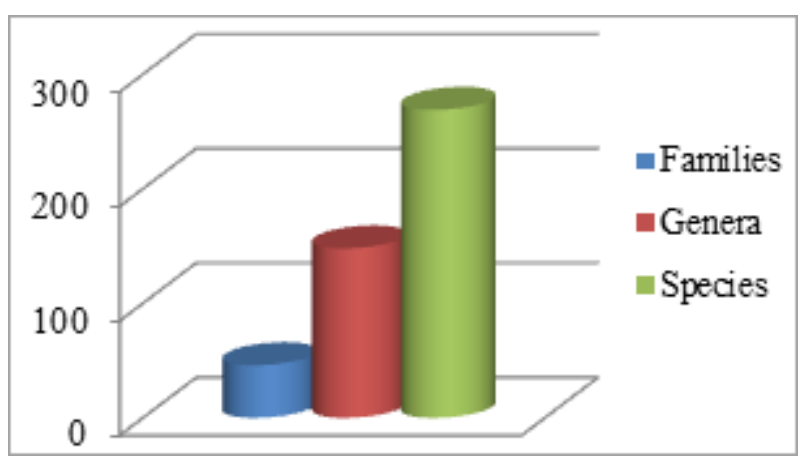

Figure 1. Quantitative indicators of taxonomic compositionof the WRCP collected in 2014

The quantitative distribution between families was unequal. The following families were characterized by the most specific content of wild relatives: Poaceae Barnhart - 66 specis, Rosaceae Juss. - 38, Fabaceae Lindl. - 28, AsteraceaeDumort. - 17, LamiaceaeLindl. - 13, PolygonaceaeJuss. - 12, Chenopodiaceae - 10; Alliaceae J. Agardh - 9, BrassicaceaeBurnett. - 7and CaprifoliaceaeJuss. -7 . The other families were represented only by 62 species of the relatives. Among them: ApiaceaeLindl. was represented by 5 species, AsparagaceaeJuss. andRanunculaceae - each by 4, GrossulariaceaeDC. иSolanaceae - by 3. The families Amaranthaceae, Berberidaceae, Betulaceae, CannabaceaeEndl., HypericaceaeJuss., Iridaceae, Moraceae Link, Malvaceae Juss., Nitariaceae,Plantaginaceae, RhamnaceaeJuss. andUrticaceae possess by 2 species. The other 11 families (AceraceaeJuss., Anacardiaceae Lindl., Asphodeliaceae, Crassulaceae, Cupressaceae, Dipsacaceae, Ephedraceae Dumort., Limoniaceae, Paeoniaceae, Valerianaceae Batsch, Viburnaceae) - onlyby 1 species.

The distribution of the wild relatives of cultivated plants by genera was also unequal. The highest number of species the following genera contain: Allium L. (9 species), Rosa (8), LoniceraL.(7), Artemisia L. (6), Agropyron, Leymus, Poa, Rumexand Cotoneaster (5). In general, the composition of these genera was 55 species. The genera contain in their composition by 4 species: Glycyrrhiza, Elymus, Hordeum, Crataegusand Asparagus. The genera containing by 3 species of the wild relatives: Bromus, Eremopyrum, Festuca,Rheum, Clematis, Sasola, Amoriaand Medicago. The genera: Elytrigia, Helictotrichon, Koeleria, Melica, Phleum, Atraphaxis, Fragaria, Malus, Rubus, Sanguesorba, Sorbus, Urtica, Amaranthus, Inula, Lactuca, Berberis, Betula, Lepidium, Kraschennikovia, Elaeagnus, Alhagi, Caragana, Hedysarum, Vicia, Ribes, Hypericum, Iris, Mentha, Salvia, Linum, Nitraria, Morus, PlantagoandCalamagrostispossess by 2 species in their composition. The other genera were presented only by 1 species. In general this group unites 112 species. The other genera of the WRCP were presented only by 1 species.

Search and collection of wild relatives of cultivated plants in 2014 was carried out in a volume of 4 floristic areas. The distribution of species by region and unevenly (as shown in "Fig. 2").

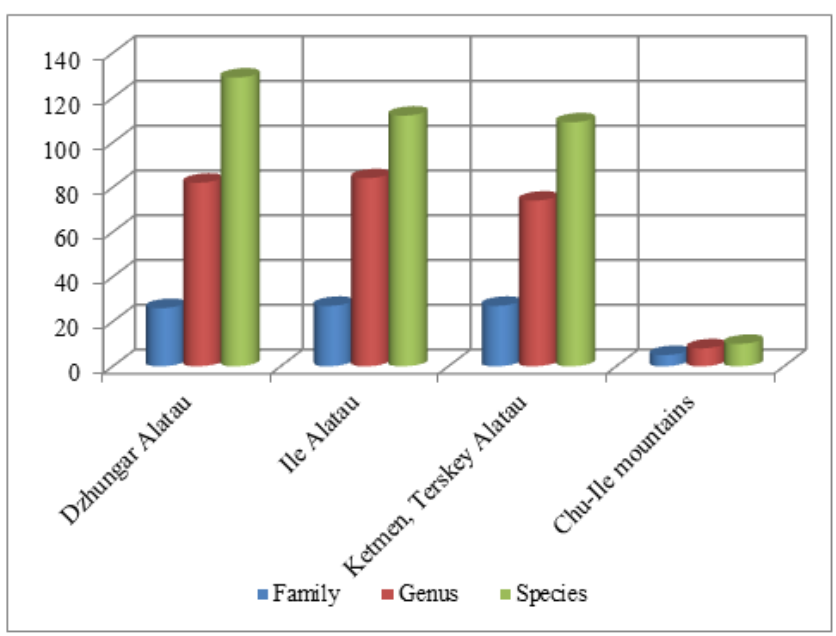

Figure 2. Distribution of the WRCP according to floristic regions

Quantitative indicators of the number of families of the WRCP were about the same: 27 families - in the Ile Alatau, and 26 - in Dzhungar Alatau and KetmenTerskey-Alatau. There were only five families in the Chu-Ili Mountains.

Generic spectrum showed similar data: the largest number of generic taxa were accounted for the Ile Alatau ( 84 species), Dzhungar Alatau (82) and KetmenTerskey-Alatau (74). In the Chu-Ili Mountains the number of genera was 8 . The distribution of the number of members collected DSKR was unequal among floristic regions. To establish a set of species growing within one or more of the studied regions, the comparative analysis of their geographic range were carried out.

Thus, it for the floristic areas Dzhungar Alatau and Ketmen-Terskey Alatau the greatest number of common species of wild relatives was revealed - 50 species.Such species as Achilleamillefolium, Achnatherumsplendens, Agropyroncristatum, Anisantha tectorum, Anthriscussylvestris, Armeniacavulgaris, Bromus squarrosus, Betulatianschanica, Brachypodiumpinnatum, Betulapendulaand others. Some lower rates of common species of the relatives were identified for the Ile Alatau and for the Ketmen-Terskey Range - 35 species represented by the following representatives: Achilleamillefolium, Agrostis gigantea, Armeniaca vulgaris,Calamagrostisepigeios, Cotoneaster melanocarpus, Dactylisglomerata, Elytrigiarepens, Leonurus turkestanicus, Lonicerahispida, Melica transsilvanica, Melilotusofficinalis, Origanumvulgare, Phleum phleoides, Plantagolanceolataand others.

The number of wild relatives marked for Ile Alatau and Dzhungar Alatau drops a little till 32 species:

Crataegus songorica, Dactylisglomerata, Daucuscarota, Deschampsia caespitosa, Elaeagnus oxycarpa, Ephedra equisetina, Glycyrrhiza uralensis, Hypericum perforatum, Elytrigiarepens, Glycyrrhizaglabra, Glycyrrhiza uralensis, Glycyrrhiza uralensis, Hypericum perforatum, Loniceratatarica, Menthalongifolia, Rosa alberti, Rosa 
beggeriana, Rosa fedtschenkoana, Rosa platyacantha, Salvia deserta, Ziziphora clinopodioidesand others.

For the floristic regions that are geographically distant from each other the number of common species of the relatives naturally drops. Since the number of common species for the Chu-Ile Mountains and Ketmen-Terskey Alatau it was 6; for the DzungarianAltatau and Chu-Ile mountains there were 5 representatives.

Despite the fact that geographically Ile Alatau and the Chu-Ile Mountains are adjacent territories, but they have a different altitude and climatic parameters. These features are reflected in the minimum quantitative composition of the common WRCP one can find there only 7 species:Elytrigiarepens, Eremodaucuslehmannii, Hypericumperforatum, Aegilops cylindrica,Poa pratensis and others. And only 3 species of the WRCP can be found within the whole studied floristic regions: Elytrigiarepens, Hypericum perforatum and Salvia deserta.

In 2014 during the implementation of the research work the points of growth of the wild relatives of cultivated plants of the number of the species included into the Red Book of Kazakhstan [30] were marked. For instance such species as Malussieversii, Armeniacavulgaris Lam., Rheum wittrockiiLundstr., PaeoniahybridaPall., Aflatuniaulmiflora, Pistaciavera andVitisvinifera.

Within the study the state of plant communities was analyzed involving the WRCP. It was revealed that in various parts the vegetation was transformed in varying degrees. In general the degree of disturbance was medium. In some places there were revealed strongly transformed areas. Steep slopes were slightly violated.

The main factors of transformation were: plowing in the foothills, changes of the river flow, canals, grazing, haying, recreation and road digression. It was noted that in the Ile Alatau the natural vegetation was not left in the steppe zone. Focusing the flowering ornamental species of tulips, irises and other ephemeroids early in spring leads to increased recreational pressure on vegetation. Within the especially protected territories (Ile-Alatau National Park, Almaty reserve, museum "Tamgalytas") natural ecosystems with WRCP were preserved.

As a result of the resource researches in the territories of 24, 25 and 25a, floristic regions (the ranges Ketmen, Terskey, Kungey and the southern slopes of Dzhungar Alatau) 93 species of the WRCP of Kazakhstan were revealed and the reserves of air-dried and fresh raw material were noted, 16 species from the following families: Rosaceae Juss. (7 species), Lamiaceae Lindl. (3), BerberidaceaeJuss. (2), AsteraceaeDumort. (1), ElaeagnaceaeJuss. (1), Polygonaceae Juss. (1), RanuncullaceaeJuss. (1).

The identified in the territory of the Ketmen ridge and southern macroslope of the Dzhungar Alatau ridge the stocks of dog rose, hawthorn Korol'kova, cotoneaster multiflori, old-man's-pepper, common origanum, mint longifolia and Ziziphoraclinopodioides can be recommended for implementation of stocking up in limited quantities and for the needs of the local network of pharmacies. For industrial stocking up the thickets of medicinal and food plants was identified, such species as: Aconitum leucostomumWorosch. andRumextianschanicus A. Los. (hr. Kungei Alatau), Berberissphaerocarpa (Ketmen) and Hippophaerhamnoides (southern slopes of the ridge Dzhungar Alatau).

The natural reserves of raw materials of the "endangered species" were taken into account: Armeniaca vulgaris Lam., Málussiéversii and Berberisiliensis. They should be used as reserve plots for the collection of seed and planting material.

Among 16 identified resource species of the WRCP of Southeastern Kazakhstan $25 \%$ of the species were provided by the raw material base and were suitable for commercial preparations. Other species of the WRCP (75\%), for which even the limited supply of raw materials in a small area were taken into account, represent a unique genetic material of biological diversity, formed under the conditions of the studied floristic regions of South-eastern Kazakhstan.

During the cameral treatment of the herbarium material collected during expeditions and revision of the herbarium funds of IBP it was found that the WRCP in the study area there were 437 taxa of parasitic fungi. Rusts occur in a quantity of 47 species (11\%), smut fungi - 44 species (10\%). Ergot pathogen is one species of fungus $(0.2 \%)$. Among the total number of detected phytopathogens 72 species of fungi (17\%) cause leaf spots of the host plant, 30 species (7\%) Septoria blotch. 3 species cause scab pathogens (1\%), leaf curl 2 species (1\%), choke diseases of cereals - 2 species (1\%), rot of fruit and roots $-36(8 \%)$, stem rot -32 species $(5 \%)$. The remaining diseases account for $39 \%$ or 185 species of fungi pathogens.

The result of breeding and genetic studies of wild apricot forests of the western part of the Ile Alatau (the Zhetyzhol ridge) 20 forms of apricot with valuable genetic traits were chosen and described. The passports for selected forms of the Armeniaca vulgaris were made. It is noted that the release forms are characterized by high polymorphism on fruit size, color, ripening, consistency pulp, taste, etc. Also from natural ecosystems of the surveyed gorges 5 plant species were selected: Morusnigra, Morusalba, Rosa platyacanthaSchrenk and Loniceramicrophylla Willd. exSchultes..

During the survey of the southern macro slope of the Dzhungar Alatau forms of the species from 5 genera were selected: hawthorn, buckthorn, barberry, dog rose and cotoneaster. It was revealed that the main anthropogenic impacts on natural ecosystems, determining the degradation of fruit forests are grazing and planting of alien tree species by the Forestry employees.

Total there were selected, marked and certified plus trees of Armeniaca vulgaris (20 copies), Morus alba (2) Morusnigra (2), Cerasustianschanica(3), Rubus caesius (2), Loniceramicrophylla (2), Crataeguskorolkowii (2), Hippophaerhamnoides L. (4), Berberisiliensis (11) Rosa platyacantha (8), Rosa laxa (12), Rosa iliensis (1), Rosa beggeriana (5), Cotoneaster melanocarpus (1) Cotoneaster meultiflorus (2), Cotoneaster megalocarpus (1).

The analysis of the intraspecific variability of generative organs (inflorescence, fruit and seed) in 15 natural populations 
of Berberisiliensis was carried out. To identify form diversity of the dimensional features the "method for detecting interference distributions" was proposed and justified.With this method there were revealed 53 forms of Berberisiliensis by gradations of sizes of metamers of the inflorescence axis, by the abundance of flowers in the brush, by the length of stalks, height and the maximum diameter of the fruits, the length and thickness of the seeds.

Form diversity of Berberisiliensis was individual and populationly was very specific. When analyzing the types of flower brushes which combining the characteristics of abundance shaped flowers, and peduncle length metameresit was determined that more than $50 \%$ of the identified 86types were populationally specific and $25 \%$ of the types were implemented only in two populations. However, two types of inflorescences brushes were revealed, each of them was required in each of the populations of this metapopulation. These types of indicators were implemented in 10-12 populations. Individual, populational, metapopulational variability of traits and their ontogenetic variability due to age, plants and fruit cluster position in the structure of the plant were demonstrated. Based on the results of the described researches the recommendations for effective conservation and breeding use of Berberisiliensis were done.

\section{Conclusion}

Thus, study of the WRCP of Kazakh part of the Northern Tien Shan revealed their botanical diversity in this area containing 269 species from 148 genera and 46 families; it was made the mobilization of reproductive material of the WRCP - 893 samples. The peculiarities of the species composition of the WRCP were studied; their phytocenotic characteristics were obtained; resource and selection-genetic evaluation of the WRCP was done; their phytopathogens were revealed; the passports of the WRCP growing in the target territory were compounded.

\section{Acknowledgments}

This work was made possible due to the state funding of Republic of Kazakhstan in the frame of the scientific-technical program No. 0199"Botanical variety of wild relatives of cultivated plants of Kazakhstan as a source of enrichment and preservation of the agrobiodiversity gene pool for realization of the Food programme", 2013-2015.

\section{References}

[1] O.N. Korovina, "Nature genepool of wild relatives of cultivated plants of the USSR Flora ant its protection,'Leningrad, 1986, P. 126.Published in Russian.

[2] R.V. Kamelin, "Great selection of humanity dawn," Barnaul, Azbuka, 2005, 126 pp.Published in Russian.

[3] E.N. Sinskaya, "N.I. Vavilov doctrine about the historical and geographical centers of the cultivated flora development," In
"Questions of geography of cultivated plants and N.I. Vavilov," Moscow-Leningrad, Nauka, 1966, pp. 22-31.Published in Russian.

[4] E.V. Wolf, "The cultural flora of the Globe," 1987, Leningrad, 324 pp.Published in Russian.

[5] AReportontheCommissiononPlantGenetic Resources, Rome Second Session, March 16-21, (1987).http://apps3.fao.org/wiews/Morocco/Paper3.jsp

[6] Agenda 21, 1992. http://univdhaka.academia.edu/SahiduzzamanSohel/Papers/36 9556/Agenda_21_Rio_Earth_Summit-1992.

[7] "Flora of the USSR," 1934-1965, Moscow-Leningrad, Publish House of the Academy of Sciences of the USSR, Vol. 1-30. Published in Russian.

[8] "Flora of KazSSR," 1956-1966,Alma-Ata, Publish House of the Academy of Science of KazSSR, Vol. 1-30. Published in Russian.

[9] "The illustrated determinant of Kazakhstan plants," edited by V.P. Goloskokov, 1972, Alma-Ata: Publish House "Nauka of KazSSR," Vol. 1, 2. Published in Russian.

[10] "The determinant of Plants of Middle Asia and Kazakhstan," 1969-1987, Tashkent: Fan, Vol. 1-9. Published in Russian.

[11] “Fieldgeobotany," 1959-1976, Moscow-Leningrad: Nauka, Vol. 1-5. Published in Russian.

[12] B.A. Bykov, "Geobotany," 1978, Alma-Ata: Nauka, 288 pp.Published in Russian.

[13] A.M. Berlyant, "Geoinformationmap-making," 1997, Moscow. 60 pp.Published in Russian.

[14] Z.V. Karamysheva, E.I. Rachkovskaya, "Experience of large-scale geobotanical map-making (for flora of the southwestern part of Central Kazakhstan Upland). Principles and methods of geobotanical map-making," 1963, Moscow-Lenungrad, 6 pp.Published in Russian.

[15] B.V. Vinogradov, "Airmethods of studying the flora of arid zones," 1960, Leningrad, 360 pp.Published in Russian.

[16] V.B. Sochava, "Geobotanical map-making. Plant classification as an ierarchi of the dynamic systems," 1972, Leningrad, pp. 33-38. Published in Russian.

[17] "Methodoly of the state evaluation and map-making of the ecosystems in extreme conditions," 1993, Puschino, 202 pp.Published in Russian.

[18] "Methodical recommendations on estimation and map-making of the modern condition of the ecosystems of the Mongol People Republic," 1989, Ulan-Bator, 107 pp.Published in Russian.

[19] E.I. Rachkovskaya, N.P. Ogar, O.V. Marynich, "Factorsoftheanthropogenictransformationandtheirinfluenceup onthefloraofKazakhstansteppes,"J. Steppebulletin, Novosibirsk, Vol. 5, pp. 22-25.Published in Russian.

[20] O.V. Marynich, "Anthropogenictransformationofthesteppeflora (for Central Kazakhstan)," thesis of the candidate of biological sciences, 1999, Almaty, 29 pp.Published in Russian.

[21] D.Tongway, "Rangeland soil condition assessment manual," 1994, Canberra: CSIRO, 69 p. 
[22] "Methods of the determination of medicine plants,"1986, Moscow, 50 pp. Published in Russian.

[23] U. Braun, "A monograph of the Erysiphales (powdery mildews)," Nova Hedwigia, 1987, Vol. 89, pp..1-700.

[24] U. Braun, R.T.A. Cook, "Taxonomic manual of the Erysiphales (powdery mildews)," 2012, RBC-KNAW Fungal biodiversity centre. Utrecht, the Netherland, $707 \mathrm{pp}$.

[25] K. Seifert, G. Morgan-Jones, W. Gams, B. Kendrick, "The Genera of Hyphomycetes" 2011,Utrecht: CBS-KNAW Fungal Biodiversity Centre. [CBS Biodiversity Series no. 2.],997 p.

[26] V.A. Bilai, E.Z. Koval, “Aspergillus. The determinant,”, 1988, Kiev: Naukovadumka, 204 pp.Published in Russian.
$[27]$

D.ASatton, A. FotergillandM. Analdi,
"Determinantofpathogenicandconditionallypathogenicfungi," 2001, Moscow, 468 pp. Published in Russian.

[28] M.A. Klich, "Identification of common Aspergillusspecies," 2002, CentraalbureauvoorSchimmelcultures, 116 p.

[29] N.I. Vavilov, "Origin centres of cultivated plants," 1926, in Proceedings on applied botany and breeding, Vol. 16, No. 2, pp. 3-48. Published in Russian.

[30] The Red book of Kazakh SSR. Part 2," 1981, Alma-Ata: Nauka, 262 pp. Published in Russian. 